\title{
SMALL STEP FOR BIOPESTICIDES
}

\author{
Commentary on the Environment
}

BY RUSS HOYLE

Not long ago the Wall Street Journal ran an editorial on California's whitefly blight entitled "Silent Harvest." With the editorial page's usual sledgehammer subtlety, the headline mocked Rachel Carson's 1962 book, Silent Spring, the seminal cri de coeur against chemical pesticides that has come to be regarded as holy writ by environmentalists. Besides taking the occasion for the thirtieth time to discredit the four-year old Alar scare, which most normal apple eaters and juice drinkers have long since forgotten, the editorial went into a long song and dance about the regulatory barriers to a "promising" new chemical pesticide not yet on the market. Were it not for $\$ 50$-million, 10-year regulatory delays, the Journal averred, this wonder product might have been on the market to trash whiteflies and save our collective canteloupes.

Of course, that's absurd. Even a regulatory process streamlined to suit the Journal's overheated convictions would not have helped in time. After all, the whitefly is not exactly the HIV virus. But there is a larger point here. Even U.S. industrial giants like DuPont (Wilmington, DE) and Monsanto (St. Louis, MO) understand that in the waning years of the 20th century, chemicals are to agriculture what high-powered, gas-guzzling internalcombustion V-8s are to the car culture: if given a choice, people do not want them around anymore. That is as true in Japan and Europe as it is in the U.S., as attested to by the interest in agricultural biopesticides on the part of big multinational chemical companies like Britain's ICI (London), Switzerland's Ciba-Geigy (Basel), France's Rhone-Poulenc (Courbevoie Cedex), and Japan's Kubota (Tokyo).

\section{DuPont backs Crop Genetics}

It is just this global potential of nonchemical alternatives, the Wall Street Journal's backwardness notwithstanding, that underlay DuPont's recent decision to pump some $\$ 3.75$ million over the next two years into Crop Genetics International's (Hanover, MD) naturally occuring insecticidal virus products. DuPont, whose chemical products now represent a 5-percent share in the \$8billion world-pesticide market, obviously believes the relatively simple natural insecticidal virus technology has significant potential, despite current limitations that include slower-than-optimal killing time and high production costs.

"We are very cognizant of the need for
The global potential of biopesticides underlies DuPont's decision to pump some $\$ 3.75$ million into Crop Genetics International.

environmentally compatible products," says Frank Owen, DuPont's global manager for insecticide products. Owen made it clear that the Crop Genetics joint venture, for which DuPont will supply the distribution and marketing muscle, represents only a facet of DuPont's longterm plans in the field.

Much of the appeal of Crop Genetics' insecticidal virus technology lies in its potential to produce a marketable product quickly. Essentially a high-tech version of grinding up virally killed insects and spraying the remains on crops, the two-stage Crop Genetics virus-manufacturing-and-purification process is reportedly fully developed. The first stage, tradenamed Alcatraz, involves mass producing mature caterpillars of such insects as the beet army worm or coddling moth under disease-free conditions. They are then inoculated with an insect-specific virus: Autographa californica, for example, which kills cabbage loopers and several heliothis species as well as beet worms and moths. Initially the new insecticidal viruses will be used on fruits and vegetables that may or may not have been treated with bacterial agents or chemical insecticides.

The second stage of the process, called Cascade (patent pending), is essentially an elaborate filtration system in which the bugs are destroyed and the pure virus separated, extracted, and collected to make the insecticide. DuPont's financial infusion will allow Crop Genetics to scale up this manufacturing process for the first time, which is expected to bring down costs to competitive levels. The process, developed by a small biotech firm named Espro, which was bought out by Crop Genetics last year, should result in a marketable insecticide by 1994 or 1995.

\section{Shorter development times}

This relatively short product-development time, industry insiders believe, made the naturally occurring Crop Genetics insecticidal virus product especially attractive for DuPont. The deal probably reflects positively as well on the strategy of other small agbiotech firms to concentrate at first on naturally occurring microbes and viruses. The questions of science, efficacy, and safety are fast becoming familiar to regulators, and thus regulatory pathways are becoming, if not well worn, at least more predictable. The ability of innovative small companies to attract second- or third-phase development capital is already tough enough without having to run regulatory high hurdles.

The biopesticide field, like pharmaceutical biotech, is plagued with long lead times. Unlike its sexier older sibling, however, it is beset by far-lessimpressive potential profit margins. This fact does not exactly turn on potential investors. Thus alliances like the Crop Genetics-DuPont partnership are becoming increasingly important to small and mid-sized biotech companies that want to keep their foot in the door commercially. Those that can demonstrate effective products in the short term probably will have the best opportunity for partnerships or joint ventures with larger companies.

\section{Access to foreign markets}

The New York Times has reported that the number of agbiotech companies willing to trade future access to foreign markets for infusions of foreign development money is on the increase. If true, it is a sobering trend. Crop Genetics (with annual sales of $\$ 2$ million) has yet to negotiate a detailed foreign-sales agreement with DuPont. But the Maryland firm, which has engineered a number of industry firsts in its 10 -year history, so far would seem to have avoided selling itself short in the potentially lucrative global marketplace by throwing in its lot with a strong U.S. partner.

What will be interesting now is the longevity of the relationship. With the amount of research going on, it is only a matter of time before pressure mounts to produce genetically engineered biopesticides-in order to increase the speed with which they destroy insects and extend the range of insects destroyedfor commercial use. The fact is, the process already has begun. In the past two years, as many as 20 percent of the agricultural products approved by the Environmental Protection Agency (Washington, DC) were genetically engineered. What is the next step? The question really is one of scientific depth and creativity. In 2002, most likely DuPont still will be around. Will Crop Genetics? 